\title{
The parasitism of Ixodes luciae (Acari: Ixodidae) on marsupials and rodents in Peruvian Amazon
}

\author{
María Mónica DÍAZ ${ }^{1,2}$, Santiago NAVA³, Alberto Alejandro GUGLIELMONE³ \\ ABSTRACT \\ In this work the infestation with I. luciae on Didelphimorphia and Rodentia in different environments of Peruvian Amazon \\ was studied. Didelphimorphia was represented by the family Didelphidae. Specimens belonging to Caluromys lanatus, \\ Didelphis marsupialis, Marmosops sp.2, Metachirus nudicaudatus, Philander andersoni and Philander opossum were infested \\ with adults I. luciae and one Micoureus sp. was infested with larvae. In Rodentia, the infestation with I. luciae nymphs was \\ restricted to Hylaeamys perenensis, Hylaeamys yunganus and Oligoryzomys microtis, while one Oecomys bicolor (all Cricetidae) \\ was infested with larvae of this species. The few larvae were found on rodents captured in primary forest. The only significant \\ difference $(\mathrm{P}<0.05)$ in prevalence of adult ticks on Didelphimorphia was between P. andersoni and M. nudicaudatus (chi- \\ square distribution). Adult tick distribution was significant different in $P$. andersoni in comparison with $M$. nudicaudatus, $P$. \\ opossum and D. marsupialis (Kruskal-Wallis test). No significant effect of month or environment was detected in relation to \\ adult tick infestation on Didelphimorphia. The prevalence of nymphal infestation as well as tick distribution showed that $H$. \\ perenensis and $H$. yunganus were significantly more prone to be infested with nymphs of $I$. luciae than $O$. microtis. Prevalence \\ of nymph infestation was higher in primary and secondary forest than rural areas while abundance was higher in secondary \\ forest when compared with rural areas $(\mathrm{P}<0.05)$. Kruskal-Wallis test showed differences $(\mathrm{P}<0.05)$ for nymphal infestation \\ during December in relation to January, March, April and June. The natural cycle of $I$. luciae appeared to be continuous, \\ bound to adult tick infestation on Philander and nymphal infestation on Hylaeamys in forested environs.
}

KEYWORDS: Ixodes luciae, ecology, Didelphimorphia, Rodentia, Peruvian Amazon.

\section{O parasitismo do Ixodes luciae (Acari: ixodidae) em marsupiais e em roedores na Amazônia Peruana}

\section{RESUMO}

No presente trabalho, infestaçóes por Ixodes luciae em Didelphimorphia e Rodentia em diferentes ambientes da Amazônia peruana foram estudadas. Didelphimorphia foi representada pela família Didelphidae. Espécimes pertencentes a Caluromys lanatus, Didelphis marsupialis, Marmosops sp., Metachirus nudicaudatus, Philander andersoni e Philander opossum foram encontrados infestadas por adultos de I. luciae; um Micoureus sp. foi encontrado infestado por larvas. Em Rodentia, a infestação por ninfas de I. luciae estiveram restritas a Hylaeamys perenensis, Hylaeamys yunganus e Oligoryzomys microtis, enquanto que um Oecomys bicolor (todos Cricetidae) esteve infestado por larvas de I. luciae. As poucas larvas foram encontradas em roedores capturados na floresta primária. A única diferença significante $(\mathrm{P}<0.05)$ na prevalência de carrapatos adultos em Didelphimorphia foi entre $P$. andersoni e $M$. nudicaudatus (distribuição chi-quadrado). A distribuição de carrapatos adultos foi significativamente diferente em $P$. andersoni quando comparado com $M$. nudicaudatus, P. opossum e D. marsupialis (teste Kruskal-Wallis). Nenhum efeito significante do mês ou ambiente foi observado em relação à infestação por carrapato adulto em Didelphimorphia. Tanto a prevalência de infestaçóes por ninfas, como a distribuição do carrapato indicaram que $H$. perenensis e $H$. yunganus estiveram mais propensos a estarem infestados por ninfas de $I$. luciae do que $O$. microtis. A prevalência de infestaçóes por ninfas foi maior em florestas primária e secundária do que em áreas rurais, enquanto que a abundância foi maior em floresta secundária, quando comparada com áreas rurais $(\mathrm{P}<0.05)$. O teste Kruskal-Wallis indicou diferenças $(\mathrm{P}<0.05)$ para infestaçôes por ninfas durante Dezembro, em relaçáo a Janeiro, Março, Abril e Junho. O ciclo natural de I. luciae parece ser continuo, destacado por adultos parasitando Philander e ninfas parasitando Hylaeamys em ambientes florestais.

PALAVRAS-CHAVE: Ixodes luciae, ecologia, Didelphimorphia, Rodentia, Amazônia Peruana.

\footnotetext{
1 Consejo Nacional de Investigaciones Científicas y Técnicas, Facultad de Ciencias Naturales e Instituto Miguel Lillo, Universidad Nacional de Tucumán, San Miguel de Tucumán (4000), Argentina. E-mail: mmonicadiaz@arnet.com.ar

2 Programa de Investigaciones de Biodiversidad Argentina, Universidad Nacional de Tucumán, Argentina

3 Instituto Nacional de Tecnología Agropecuaria, CC 22, CP 2300 Rafaela, Santa Fe, Argentina. E-mail: snava@rafaela.inta.gov.ar
} 


\section{INTRODUCTION}

Ixodes luciae Sénevet, 1940 is a Neotropical tick species whose preferential hosts are marsupials for adult stages and small rodents for subadults ticks according to Hoogstraal and Aeschlimann (1982). Nevertheless, there are several records of marsupials infested with larvae and nymphs of this tick species (Jones et al. 1972; Autino et al. 2006). Ixodes luciae is widely distributed from southern Mexico to Argentina including several Caribbean islands (Guglielmone et al. 2003). There is an Argentinean record of a female of I. luciae parasitizing human (Ivancovich and Luciani 1992) but there is not information to consider it a vector of human or animal diseases. Main aspects of the ecology of I. luciae are basically unknown. Therefore, a study was conducted during a period of 37 months to evaluate the infestation with $I$. luciae on Didelphimorphia and Rodentia in different environments in Peruvian Amazon to increase our knowledge on the natural cycle of this tick species.

\section{MATERIALS AND METHODS}

Small and medium sized Didelphimorphia and Rodentia were captured with live traps and pit fall traps, and inspected for ticks monthly from December 2002 to December 2005 along the highway Iquitos-Nauta, Department of Loreto in Peruvian Amazon. Several replicate trap lines $(500 \mathrm{~m}$ in length) were located along the Iquitos-Nauta Highway, places in three different habitats: one in primary forest, one in rural area (i.e., chacra), and one in secondary forest (i.e., purma). Each line contained 50 traps stations (10 m spacing) comprising a Sherman and Tomahawk traps and were sampled for seven nights. Traps were baited with peanut butter, oats, and fruits. Pit fall traps were placed outside of the line traps in primary or secondary forest, between three and six buckets were spaced at $5 \mathrm{~m}$ intervals along a transect. In total, 21 localities were sampled in the primary forest, 31 in secondary forest, and 36 in rural areas.

The primary forest is characterized by high tree diversity with $30 \mathrm{~m}$ canopy interrupted by $50 \mathrm{~m}$ trees in upland and wetland forest. Leguminosae (Fabaceae) is the most diverse family in Iquitos primary forest, but other prevalent woody families are Moraceae, Lauraceae, Annonaceae, Rubiaceae, Myristicaceae, Sapotaceae and Meliaceae. Palms are well represented, especially on richer soils, and locally endemic species include Meliosma vazquezii, Caraipa utilis and Aptandra caudate (see Gentry 1988a, b, 1991; Vásquez and Gentry 1988, Gentry and Ortiz-S 1993 for further details). The secondary forest differs from the first one in the species composition and a canopy less than $10 \mathrm{~m}$ and dense understory (area of a forest which grows in the shade of the emergent or forest (canopy). Plants in the understory consist of a mixture of seedlings and saplings of canopy trees together with understory shrubs and herbs), where Bombacaceae, Cecropiaceae, Leguminoseae, Bignoniaceae and Moraceae are common (Vásquez-Martínez and Rojas Gonzales 2002). The rural area included agricultural lands planted with pineapple (Anana comosus), yucca (Manihot esculenta), banana (Musa spp.) and fruit trees such as pijuayo or peach palm (Bactris gasipaes), uvilla or Amazon tree-grape (Pourouma cecropiifolia), umari (Poraqueiba sericea) or mango (Mangifera indica), plus suburban areas.

The climate is relatively uniform. The mean annual temperature is $27.5^{\circ} \mathrm{C}$ with a few variations along the year. Although temperatures are relatively constant, June to December is the hottest period. The mean annual rainfall is $2700 \mathrm{~mm}$ with no well-marked dry season.

The ticks were recovered by hand from the host coat with magnifying lens and preserved in 70\% ethanol, and then were carried to the laboratory for the taxonomic determination according to Díaz et al. (2007). Didelphimorphia and Rodentia were identified from several sources and taxonomic classification was made following Wilson \& Reeder (2005), except in Sigmodontinae: Oryzomyini where Weksler et al. (2006) was followed.

Chi-square distribution and test of Kruskal-Wallis were used as main statistical tools to determine significant differences in prevalence [(number of hosts infested with ticks / number of examined hosts) X 100] and tick abundance distributions, respectively, amongst hosts, months and environments. Mean was selected as central parameter because almost invariably the median numbers were 0 .

The mammals are deposited in the Museo de Historia Natural de la Universidad Nacional Mayor de San Marcos, Lima, Peru, and ticks in the annexes of the Colección Mamíferos Lillo (CML), Universidad Nacional de Tucumán, Tucumán, Argentina and in the Estación Experimental IVITA (Instituto Veterinario de Investigaciones Tropicales y de Altura), Iquitos, Peru.

\section{RESULTS}

The number of different species of Didelphimorphia and Rodentia captured and their status regarding the infestation with $I$. luciae is presented in Table 1. Didelphimorphia was represented only by the family Didelphidae. Specimens of the genus Glironia, Marmosa and Monodelphis as well as Didelphis albiventris, Marmosops bishopi, Marmosops sp. and Philander sp. were not found infested with I. luciae. The total captured specimens from these uninfested genera and species (108 specimens) represented $29.2 \%$ of the total 370 Didelphimorphia captured. The species infested with $I$. luciae comprises specimens of Caluromys lanatus, Didelphis marsupialis, Marmosops sp., Metachirus nudicaudatus, 
Table 1 - Number of different families and species of Didelphimorphia and Rodentia captured in Peruvian Amazon and their status in relation to the infestation with different stages of Ixodes luciae.

\begin{tabular}{|c|c|c|c|c|}
\hline \multirow{2}{*}{ HOSTS } & \multirow{2}{*}{$\mathrm{N}$} & \multicolumn{3}{|c|}{ Ixodes luciae } \\
\hline & & Larva & Nymph & Adults \\
\hline \multicolumn{5}{|l|}{ DIDELPHIMORPHIA } \\
\hline \multicolumn{5}{|l|}{ Didelphidae } \\
\hline Caluromys lanatus & 9 & No & No & Yes \\
\hline Didelphis albiventris & 1 & No & No & No \\
\hline Didelphis marsupialis & 28 & No & No & Yes \\
\hline Glironia venusta & 1 & No & No & No \\
\hline Marmosa sp. & 2 & No & No & No \\
\hline Marmosops sp.1 & 21 & No & No & No \\
\hline Marmosops sp.2 & 3 & No & No & Yes \\
\hline Marmosops bishopi & 10 & No & No & No \\
\hline Marmosops noctivagus & 69 & No & No & No \\
\hline Metachirus nudicaudatus & 33 & No & No & Yes \\
\hline Micoureus sp. & 26 & Yes* & No & No \\
\hline Monodelphis adusta & 2 & No & No & No \\
\hline Philander sp. & 2 & No & No & No \\
\hline Philander andersoni & 10 & No & No & Yes \\
\hline Philander opossum & 153 & No & No & Yes \\
\hline \multicolumn{5}{|l|}{ RODENTIA } \\
\hline \multicolumn{5}{|l|}{ Cricetidae } \\
\hline Holochilus sciureus & 12 & No & No & No \\
\hline Hylaeamys sp. & 2 & No & No & No \\
\hline Hylaeamys perenensis & 33 & No & Yes & No \\
\hline Hylaeamys yunganus & 35 & No & Yes & No \\
\hline Neacomys spinosus & 41 & No & No & No \\
\hline Neacomys sp.** & 31 & No & No & No \\
\hline Nectomys apicalis & 6 & No & No & No \\
\hline Oecomys sp.1 & 2 & No & No & No \\
\hline Oecomys sp.2 & 1 & No & No & No \\
\hline Oecomys sp.3 & 3 & No & No & No \\
\hline Oecomys bicolor & 6 & Yes* & No & No \\
\hline Oecomys cf. paricola & 1 & No & No & No \\
\hline Oligoryzomys microtis & 46 & No & Yes & No \\
\hline Rhipidomys leucodactylus & 1 & No & No & No \\
\hline Scolomys melanops & 7 & No & No & No \\
\hline Scolomys sp. & 2 & No & No & No \\
\hline \multicolumn{5}{|l|}{ Echimyidae } \\
\hline Isothrix bistriata & 1 & No & No & No \\
\hline Makalata rhipidura & 2 & No & No & No \\
\hline Mesomys hispidus & 10 & No & No & No \\
\hline Proechimys brevicauda & 118 & No & No & No \\
\hline Proechimys cuvieri & 208 & No & No & No \\
\hline Proechimys quadruplicatus & 97 & No & No & No \\
\hline Proechimys sp.1 & 14 & No & No & No \\
\hline Proechimys sp.2 & 5 & No & No & No \\
\hline \multicolumn{5}{|l|}{ Sciuridae } \\
\hline Microsciurus flaviventer & 2 & No & No & No \\
\hline
\end{tabular}

* Tentatively considered to belong to I. luciae but indistinguishable from I. loricatus ** Probably more than one species 
Philander andersoni and Philander opossum for a total of 262 individuals ( $70.8 \%$ of the total captured).

Different was the situation with Rodentia because all members of the families Echimyidae and Sciuridae, which represented $66.7 \%$ of the total capture of rodents (457 specimens of 686), were found free of I. luciae. The infestation was restricted to the family Cricetidae but only Hylaeamys perenensis, Hylaeamys yunganus, Oecomys bicolor and Oligoryzomys microtis, that corresponded to $17.5 \%$ of the total of Rodentia (120 of 686) and $52.4 \%$ of Cricetidae (120 of 229) captured, respectively, had at least one individual infested.

A total of 3 larvae, 43 nymphs and 27 adults (26 females and 1 male) were collected. The details of infestation are presented in Table 2. The diagnosis of the larva of $I$. luciae is tentative, because we were unable to distinguish it from Ixodes loricatus Neumann, 1899, other ixodid whose adults are common on Didelphimorphia and subadults on Cricetidae (Nava et al. 2004). These larvae were collected on hosts captured in primary forest in April and June 2005 but the few records precluded any further consideration.

Table 2 - Prevalence (\%) of infestation with larva, nymph and adult of Ixodes luciae along with corresponding mean and standard deviations in different species of Didelphimorphia and Rodentia families captured in Peruvian Amazon. Number of hosts (n) represented only the species found infested with this tick species as listed in Table 1.

\begin{tabular}{|c|c|c|c|c|}
\hline Larva * & $n$ & Prevalence ** & Total tick No & Mean $\pm S D^{\star * *}$ \\
\hline \multicolumn{5}{|l|}{ DIDELPHIMORPHIA } \\
\hline Micoureus sp. & 26 & $3.8 \mathrm{a}$ & 2 & $0.1 \pm 0.39 a$ \\
\hline \multicolumn{5}{|l|}{ RODENTIA } \\
\hline Oecomys bicolor & 6 & $16.6 \mathrm{a}$ & 1 & $0.2 \pm 0.41 a$ \\
\hline \multicolumn{5}{|l|}{ Nymph } \\
\hline \multicolumn{5}{|l|}{ RODENTIA } \\
\hline $\begin{array}{l}\text { Hylaeamys } \\
\text { perenensis }\end{array}$ & 33 & $24.2 \mathrm{a}$ & 19 & $0.6 \pm 1.66 a$ \\
\hline $\begin{array}{l}\text { Hylaeamys } \\
\text { yunganus }\end{array}$ & 35 & $25.7 \mathrm{a}$ & 23 & $0.7 \pm 1.83 a$ \\
\hline $\begin{array}{l}\text { Oligoryzomys } \\
\text { microtis }\end{array}$ & 46 & $2.4 b$ & 1 & $<0.1 \pm 0.15 b$ \\
\hline \multicolumn{5}{|l|}{ Adult } \\
\hline \multicolumn{5}{|l|}{ DIDELPHIMORPHIA } \\
\hline Caluromys lanatus & 9 & $11.1 a b$ & 1 & $0.1 \pm 0.33 a b$ \\
\hline $\begin{array}{l}\text { Didelphis } \\
\text { marsupialis }\end{array}$ & 28 & $3.6 a b$ & 1 & $<0.1 \pm 0.19 b$ \\
\hline Marmosops sp.2 & 3 & 33.3ab & 1 & $0.3 \pm 0.58 a b$ \\
\hline $\begin{array}{l}\text { Metachirus } \\
\text { nudicaudatus }\end{array}$ & 33 & $3.0 \mathrm{a}$ & 1 & $<0.1 \pm 0.17 b$ \\
\hline Philander andersoni & 10 & $40.0 b$ & 4 & $0.4 \pm 0.52 a$ \\
\hline Philander opossum & 153 & $11.1 a b$ & 19 & $0.1 \pm 0.37 \mathrm{~b}$ \\
\hline
\end{tabular}

* Tentatively considered to belong to I. Iuciae but indistinguishable from I. Ioricatus $\star *$ Chi-square distribution. Numbers followed by different letter are statistically different $(\mathrm{P}<0.05)$

$\star \star \star$ Test of Kruskal-Wallis. Numbers followed by different letter are statistically different $(P<0.05)$
The only significant difference in prevalence of adult ticks on Didelphimorphia was between $P$. andersoni and $M$. nudicaudatus. (Table 2). Kruskal-Wallis test showed that the adult tick distribution was significant different in $P$. andersoni in comparison with $M$. nudicaudatus, P. opossum and D. marsupialis. No significant effect of month or environment was detected in relation to adult tick infestation on Didelphimorphia (Tables 3 and 4) but all hosts found infested in rural areas were P. opossum.

Table 3 - Prevalence (\%) of infestation of adults of Ixodes luciae on Didelphimorphia and nymphs on Rodentia along with corresponding means and standard deviations from specimens captured in Peruvian Amazon. Number of hosts (n) represented only the species found infested with adults and nymphs of this tick species as listed in Table 2.

\begin{tabular}{|c|c|c|c|c|}
\hline Adult ticks & $\mathrm{n}$ & Prevalence* & Total tick No & Mean $\pm S D^{\star *}$ \\
\hline January & 12 & $8.3 a$ & 1 & $0.1 \pm 0.29 a$ \\
\hline February & 20 & $10.0 \mathrm{a}$ & 2 & $0.1 \pm 0.31 a$ \\
\hline March & 20 & $10.0 \mathrm{a}$ & 3 & $0.2 \pm 0.49 a$ \\
\hline April & 9 & $22.2 \mathrm{a}$ & 2 & $0.2 \pm 0.44 a$ \\
\hline May & 20 & $10.0 \mathrm{a}$ & 2 & $0.1 \pm 0.31 a$ \\
\hline June & 28 & $10.7 \mathrm{a}$ & 3 & $0.1 \pm 0.32 \mathrm{a}$ \\
\hline July & 22 & $0 \mathrm{a}$ & 0 & $0 \mathrm{a}$ \\
\hline August & 10 & $0 \mathrm{a}$ & 0 & Oa \\
\hline September & 17 & $23.5 a$ & 5 & $0.3 \pm 0.59 a$ \\
\hline October & 25 & $8.0 \mathrm{a}$ & 2 & $0.1 \pm 0.28 a$ \\
\hline November & 41 & $17.1 \mathrm{a}$ & 7 & $0.2 \pm 0.38 \mathrm{a}$ \\
\hline December & 12 & $0 \mathrm{a}$ & 0 & Oa \\
\hline \multicolumn{5}{|l|}{ Nymphs } \\
\hline January & 19 & $21.0 \mathrm{a}$ & 7 & $0.4 \pm 0.96 a$ \\
\hline February & 8 & $0 \mathrm{a}$ & 0 & 0ab \\
\hline March & 9 & $33.3 a$ & 4 & $0.4 \pm 0.73 a$ \\
\hline April & 6 & $50.0 \mathrm{a}$ & 12 & $2.0 \pm 3.95 a$ \\
\hline May & 6 & $0 \mathrm{a}$ & 0 & Oab \\
\hline June & 19 & $21.1 \mathrm{a}$ & 6 & $0.3 \pm 0.67 a$ \\
\hline July & 2 & $0 \mathrm{a}$ & 0 & $0 a b$ \\
\hline August & 6 & $0 \mathrm{a}$ & 0 & $0 a b$ \\
\hline September & 14 & $14.3 a$ & 12 & $0.9 \pm 2.48 a b$ \\
\hline October & 1 & $100 \mathrm{a}$ & 1 & $1.0 a b$ \\
\hline November & 5 & $20.0 \mathrm{a}$ & 1 & $0.2 \pm 0.45 a b$ \\
\hline December & 19 & $0 \mathrm{a}$ & 0 & ob \\
\hline
\end{tabular}

${ }^{*}$ Chi-square distribution. Numbers followed by different letter are statistically different $(P<0.05)$
$* *$ Test of Kruskal-Wallis. Numbers followed by different letter are statistically different $(P<0.05)$

The nymph infestation was strongly related to parasitism of the two species of Hylaeamys detected in Peruvian Amazon. Hylaeamys perenensis and $H$. yunganus were significantly more prone to be infested with nymphs of $I$. luciae than $O$. microtis (Table 2). This last host showed a minimal infestation (1 parasitized of 46 specimens caught). Although Kruskal-Wallis test showed statistical differences for December in relation to January, March, April and June (Table 3), this difference vanish when the data regarded $O$. microtis are excluded $(\mathrm{P}=$ 
0.366, data not shown). Prevalence of nymphal infestation was higher in secondary and primary forest than in rural areas and abundance was higher on rodents captured in secondary forest than in hosts captured in rural areas (Table 4).

Table 4 - Prevalence (\%) of infestation of adults of Ixodes luciae on Didelphimorphia and nymphs on Rodentia along with corresponding means and standard deviations from specimens captured in primary forest, secondary forest and rural area in Peruvian Amazon. Number of hosts (n) represented only the species found infested with this adults and nymphs of this tick species as listed in Table 2.

\begin{tabular}{lcccc}
\hline \multicolumn{1}{c}{ Adult ticks } & $\mathrm{n}$ & Prevalence $^{*}$ & Total tick N $^{0}$ & Mean $\pm \mathrm{SD}^{\star *}$ \\
\hline Primary forest & 67 & $6.0 \mathrm{a}$ & 4 & $0.1 \pm 0.24 \mathrm{a}$ \\
Secondary forest & 134 & $11.2 \mathrm{a}$ & 16 & $0.1 \pm 0.35 \mathrm{a}$ \\
Rural area & 34 & $15.6 \mathrm{a}$ & 7 & $0.2 \pm 0.48 \mathrm{a}$ \\
\hline \multicolumn{1}{c}{$\quad$ Nymphs } & & & & \\
\hline Primary forest & 49 & $22.4 \mathrm{a}$ & 14 & $0.3 \pm 0.57 \mathrm{ab}$ \\
Secondary forest & 27 & $22.2 \mathrm{a}$ & 28 & $1.0 \pm 1.32 \mathrm{a}$ \\
Rural area & 38 & $2.6 \mathrm{~b}$ & 1 & $<0.1 \pm 0.16 \mathrm{~b}$ \\
\hline
\end{tabular}

* Chi-square distribution. Numbers followed by different letter are statistically different $(P<0.05)$

$\star \star$ Test of Kruskal-Wallis. Numbers followed by different letter are statistically different $(P<0.05)$

\section{DISCUSSION}

Indeed the natural cycle of I. luciae in the study area is bound to the infestation of adult ticks on Didelphimorphia and nymphs on Rodentia (Cricetidae: Sigmodontinae: Oryzomyini) partly supporting the statement of Hoogstraal \& Aeschlimann (1982) already mentioned in the introduction. Nevertheless, the situation is not so clear for the larval stage because just one Didelphimorphia and one Rodentia (Cricetidae) were infested. The compilation of the findings of larvae of $I$. luciae constructed by one of the authors (AAG, available upon request) showed one finding on $D$. albiventris in Bolivia (Fonseca 1959), on rodents (without any further elaboration) in Trinidad \& Tobago (Fairchild et al. 1966), six records on Monodelphis brevicaudata, one on Marmosa robinsoni, one on Oecomys concolor and one on Sigmodon hispidus in Venezuela (Jones et al. 1972) (name of hosts as presented by the authors). Therefore additional studies are needed to recognize the preferential hosts for the larvae of I. luciae.

Although it was a tendency of adult ticks to feed on Philander species, six of the 15 species of Didelphimorphia were found infested with this tick stage, indicating that frequent (Philander) or alternative hosts ( $C$. lanatus, $D$. marsupialis, Marmosops sp. and M. nudicaudatus) would be useful for the maintenance of this tick species in nature. Different was the situation with the nymphs of I. luciae. Only three of the 16 species of Cricetidae were found infested with nymphs of I. luciae but $98 \%$ of them were found on Hylaeamys, indicating that nymphs of this tick species are probably highly dependent on the presence of this type of host in the study site.

No any strong seasonal trend of adults and nymphs of I. luciae was detected. This is probably a consequence of a continuous life cycle under rather uniform climatic conditions just south of the Equator with a superposition of stages of different tick generations. Nevertheless, low tick abundance and number of hosts inspected may have affected the detection of seasonal trends that could be determined with a collection period longer than the 37 months used for this study and increasing the capture.

No significant effect of environment was observed in relation to adult tick infestation. On the other hand, hosts captured in rural areas showed a low prevalence of nymph infestation while abundance of I. luciae nymphs was highest in host captured in secondary forests indicating that forested areas are more important to sustain nymphal populations than rural environment. This appears to be inconsistent because if nymphs prevail in forested habitats these should be the sites for host-finding of adults derived from those nymphs. However, it was not reflected in the analysis of adult tick infestation. This is probably bound to mobility of $P$. opossum among environments because this was the only host infested with adults of I. luciae in rural areas. We hypothesized that they become infested in forested environs and captured in rural areas since Philander sleep during the day under tree roots or in hollow trees in the forest and they are capable to explore different habitats (about 25,000 $\mathrm{m}^{2}$ ) during the night (Hershkovitz, 1997).

Important hosts for I. luciae as $P$. anderson $i$ is established in South of Venezuela, West Brazil, East Colombia, Ecuador and Peru, while the range of $P$. opossum comprises and ample region from Tamaulipas in Mexico to Bolivia and south-center Brazil (Wilson \& Reeder 2005). The genus Hylaeamys is distributed from Venezuela and Guianas southward throughout Amazonia and the Atlantic rainforest to Paraguay and northern Argentina (Weksler et al. 2006). Hylaeamys perenensis is distributed from eastern Peru, central and southern-east Colombia, eastern Ecuador, eastern Bolivia and western-central Brazil, while H. yunganus is established from the Guianas and South of Venezuela to central Brazil, including central Colombia, eastern Ecuador, eastern Peru and northern Bolivia (Wilson \& Reeder 2005). As stated in the introduction, the distribution of the Neotropical I. luciae is wide. Therefore, considering the low number of ticks collected in spite the high number of marsupials and rodents examined, it would be of interest to understand the interrelationship between these hosts and I. luciae in environments different to Peruvian Amazon surrounding Iquitos. 


\section{ACKNOWLEDGEMENTS}

We acknowledge the support of PIDBA (Programa de Investigaciones de Biodiversidad Argentina) to MMD. INTA and Asociación Cooperadora del INTA Rafaela supported the work of SN and AAG. MMD thank to Joseph Vinetz, the principal investigator of the grants (grant No. 1R01TW005860; United States Public Health Service National Institute of Allergy and Infectious Diseases, USA) that supported the fieldwork in Peru; to the IVITA for process part of the specimens especially to veterinarian Nofre Sánchez. We also acknowledge the collaboration of field workers principally to Harold Portocarrero, and the Instituto Nacional de Recursos Naturales (INRENA), Ministerio de Agricultura of Peru for permits to capture and collect.

\section{LITERATURE CITED}

Autino, A.G.; Nava, S; Venzal, J.M.; Mangold, A.J; Guglielmone, A.A. 2006. La presencia de Ixodes luciae en el noroeste argentino y nuevos huéspedes de para Ixodes pararicinus y algunas especies de Amblyomma (Acari: Ixodidae). Revista de la Sociedad Entomológica Argentina, 65: 27-32.

Díaz, M.M.; Nava, S.; Venzal, J.M.; Sánchez, N.; Guglielmone, A.A. 2007. A tick collection from Peruvian Amazon with new host records for species of Ixodes Latreille, 1795 (Acari: Ixodidae) and Ornithodoros Koch, 1844 (Acari: Argasidae). Systematic and Applied Acarology, 12: 127-133.

Fairchild, G.B.; Kohls, G.M.; Tipton V.J. 1966. The ticks of Panama (Acarina: Ixodoidea). In: Wenzel, W.R.; Tipton, V.J. (Eds). Ectoparasites of Panama). Field Museum of Natural History, Chicago. p. 167-219.

Fonseca, F. 1959. Notas de acarología. XLIVI. Acarofauna zooparasita na Bolivia. Memórias do Instituto Butantan, 29: 89-141.

Gentry, A.H. 1998a. Changes in plant community diversity and floristic composition on environmental and geographical gradients. Annals of the Missouri Botany Garden, 75: 1-4.

Gentry, A.H. 1988b. Tree species richness of Upper Amazonian forests. Proceedings of the National Academic of Science USA, 85: 156-159.

Gentry, A.H. 1991. The distribution and evolution of climbing plants. In: Putz, F.A.; Mooney, H.A. (Eds.). Biology of vines. Cambridge University Press, Cambridge. p. 3-52

Gentry, A.H.; Ortiz-S, R. 1993. Patrones de composición florística en la Amazonia peruana. In: Kalliola. R.; Puhakka, M.; Danjoy, W (Eds.). Amazonia peruana vegetación húmeda subtropical en el llano subandino. Proyecto Amazonia Universidad de Turku and Oficina Nacional de Evaluación de Recursos Naturales, Jyväskylä, Finland. p. 155-166
Guglielmone, A.A.; Estrada-Peña A.; Keirans, J.E.; Robbins, R.G. 2003. Ticks (Acari: Ixodidae) of the Neotropical Zoogeographic Region. Special Publication, International Consortium on Ticks and Tick-borne Diseases, Atalanta, Houten, The Netherlands, 173pp.

Hershkovitz, P. 1997. Composition of the family Didelphidae Gray, 1821 (Didelphoidea: Marsupialia), with a review of the morphology and behavior of the included four-eyes pouched opossums of the genus Philander Tiedemann, 1808. Fieldiana: Zoology, 86:1-103.

Hoogstraal, H; Aeschlimann, A. 1982. Tick-host specificity. Bulletin de la Société Entomologique Suisse, 55: 5-32.

Ivancovich, J.C.; Luciani, C.A. 1992. Las garrapatas de Argentina. Monografía de la Asociación Argentina de Parasitología Veterinaria, Buenos Aires, 95pp.

Jones, E.K; Clifford, C.M; Keirans, J.E.; Kohls, G.M. 1972. The ticks of Venezuela (Acarina: Ixodoidea) with a key to the species of Amblyomma in the Western Hemisphere. Brigham Young University Science Bulletin, Biological Series, 17: 1-40.

Nava, S.; Lareschi, M.; Beldoménico, P.M.; Zerpa, C.; Venzal, J.M.; Mangold, A.J.; Guglielmone, A.A. 2004. Sigmodontinae rodents as hosts for larvae and nymphs of Ixodes loricatus Neumann, 1899 (Acari: Ixodidae). Parasite, 11: 411-414.

Vásquez, R.; Gentry, A.H. 1989. Use and misuse of forest-harvested fruit in the Iquitos area. Conservation Biology, 3: 350-361.

Vásquez Martínez, R.; Rojas Gonzales, R.P. 2002. Flores de la Amazonia peruana: clave de identificación de familias: Gymnospermae and Angiospermae. Missouri Botanical GardenPerú Centro para la Conservación y Desarrollo Sostenible. Versión 1.0, http://www.jbmperu.org/gyman/index.htm.

Weksler, M.; Percequillo, A.R.; Voss, R.S. 2006. Ten new genera of oryzomyine rodents (Cricetidae: Sigmodontinae). American Museum Novitaties, 3537: 1-29.

Wilson, D.E.; Reeder, D.M. 2005. Mammals species of the World. The John Hopkins University Press, Baltimore, U.S.A. 2142 pp.

Recebido em 20/02/2008

Aceito em 14/09/2009 